\title{
A narrative investigation on the motivation to become an entrepreneur among a sample of black entrepreneurs in South Africa: Implications for entrepreneurship career development education
}

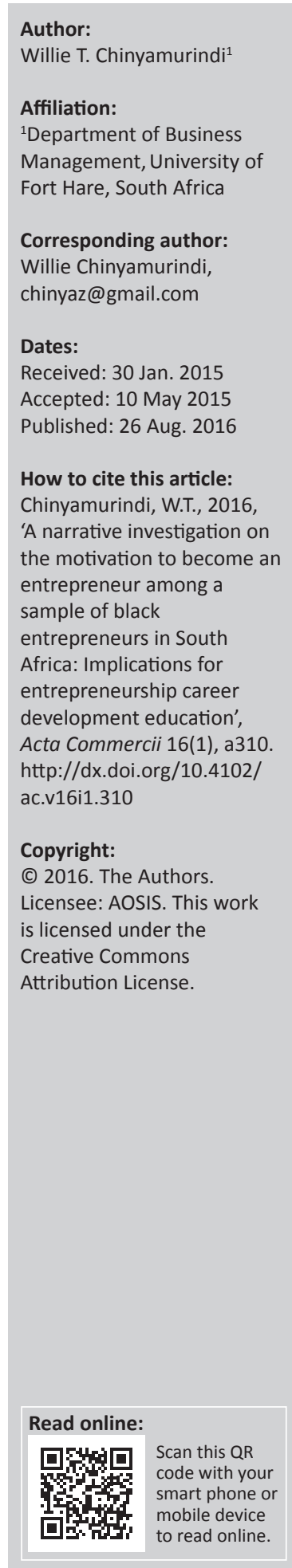

Orientation: To understand the motivation into becoming an entrepreneur. This has the basis for informing entrepreneurship career development education.

Research purpose: The study sought to understand what motivates an individual into becoming an entrepreneur.

Motivation for the study: Entrepreneurship offers an opportunity as a career choice. By studying the factors that motivate an individual to become an entrepreneur, insights could be provided on how to motivate the opportunities in entrepreneurship for current and future entrepreneurs.

Research design, approach and method: The research made use of the qualitative approach based on studying narratives and stories of 13 black entrepreneurs. The data were sourced from a popular television show in South Africa that showcases the lives of successful South Africans, including entrepreneurs.

Main findings: Motivation in becoming an entrepreneur is framed by individuals through a broad theme of opportunity. Three main sub-themes emerge under this main theme of opportunity: (a) entrepreneurship: an opportunity out of struggle; (b) entrepreneurship: an opportunity for individual self-development and (c) entrepreneurship: an opportunity for service.

Practical/managerial implications: Lecturers and facilitators in the field of entrepreneurship career development education can use the findings of this research in their teaching practice in motivating students to consider entrepreneurship as a career choice.

Contribution/value add: The findings from this research provide useful suggestions in helping lecturers and facilitators, especially within a university setting at the undergraduate level. The end desire here is to position entrepreneurship not just as a theoretical construct, but as an individual option that can be a career choice.

\section{Introduction}

South Africa is faced by a challenge of a high rate of unemployment. Entrepreneurial start-ups are being encouraged as a solution to this challenge (Chimucheka 2014). The education of future entrepreneurs can be viewed as a catalyst for crafting individuals into becoming entrepreneurs (Ibarra \& Petriglieri 2010), allowing them to re-story their lives and personal circumstance (Harmeling 2011). Thus, in South Africa, efforts are being directed towards the emergence of more entrepreneurs to develop the country (Fatoki \& Garwe 2010). Despite these efforts, others allude that South Africa still has a low rate of individuals intending to be entrepreneurs compared to individuals in other developing countries (Wolhuter 2011). Further, South Africa is witnessing a high rate of unemployed graduates (Muofhe \& Du Toit 2011) who are unable to secure jobs within the corporate sector. Chimucheka (2014) argues for the development of initiatives that encourage entrepreneurial intent, especially within a South African context, coupled with challenges such as a high unemployment rate.

A solution could be to encourage entrepreneurial intent and channelling efforts towards entrepreneurship education. Chimucheka (2014) argues that entrepreneurship education in the South African society may solve the socio-economic challenges faced by ordinary citizens. 
However, empirically little is known about entrepreneurship education, especially within higher education (Ghina 2014) albeit the popularity of courses and curricular around entrepreneurship in most South African universities.

A challenge that often exists is in how courses and curricular with an entrepreneur education focus are presented within higher education. There appears to be no agreement on the teaching methods and pedagogy around entrepreneurship education (Fayolle \& Gailly 2008). This places difficulty in evaluating the impact of entrepreneurship education initiatives in general (Harte \& Stewart 2012). Educators, when teaching entrepreneurship, are being encouraged to opt for an approach that allows for mentoring and facilitation rather than the traditional prescriptive pedagogical format (Maritz, Jones \& Shwetzer 2015). This calls for a re-think not only into the methods in which entrepreneurship content is planned but also how it is presented.

The study also sought to understand what motivates an individual into becoming an entrepreneur based on a sample of black individuals operating in South Africa and drawing some lessons to be used with regards to entrepreneurship career development education. The source of the data used in this study is somewhat novel given the call by LaPointe and Heilmann (2014) for studies that explore how career narratives can be generated using media sources. The thinking here is that the media can be a useful source of information that shapes cultural meaning and norms (Fairclough 1995). This has led for calls to 'reconsider' alternative sources of data when researching careers and consider media sources (Cohen \& Duberley 2013:165). Table 1 outlines examples of studies that have been conducted using various media sources to understand careers and career development.

Notably, no study in South Africa has answered calls to study careers and career development using media sources albeit the growth of media in South Africa portraying the lives of entrepreneurs. These shows, mostly in the electronic media, aim not only to educate but also be instrumental in the generation of new entrepreneurs in South Africa. For career researchers, this is a potential source of data that may be key in providing a 'new direction' within the career literature (Cohen \& Duberley 2013:165). Further to this, the use of stories and narratives to study career entrepreneurs relying on media sources is gaining popularity internationally (e.g. Shen \& Yuan 2013). In South Africa, this may, potentially, offer an opportunity for career counsellors and educators to provide better help to their clients through studying their lived experiences (White 2007). However, no study in
South Africa appears to have used either media sources of data to understand careers and career development but also confined this to the context of entrepreneurship. This research seeks to add to this growing area of research inquiry.

An example of a media show that can be used to fill the identified gap is a television show run in South Africa called 'Against All Odds' that is screened weekly on South Africa's first 24-hour news channel. The show presents the lives of South Africans making a difference in their communities. Notably, attention is also given to the lives of ordinary citizens and their journey in becoming entrepreneurs. For a career researcher and avid fan of this television show, the researcher draws some reflections (based on the narratives of the black entrepreneurs) that can also be helpful within teaching practice. The thinking here is that such stories of entrepreneurial experience can serve as motivation to other individuals to start their own businesses (Christensen \& Johnston 2003). Young people uncertain about their career paths can then draw from these stories potentially as a source of influence and inspiration (Maree 2014). This may possibly motivate generation of entrepreneurs as problem solvers to societal and community challenges.

\section{Entrepreneur careers}

Entrepreneurial careers consist of those individuals who decide on self-employment as a means of sustenance and starting their own business ventures (Schreuder \& Coetzee 2013:36). Entrepreneurial careers have been described as a 'new type of career' (Inkson 2007:133) albeit the unpredictability and instability that accompanies it (Feldman \& Bolino 1996). Interestingly, research focusing on entrepreneurship education's influence on individual self-employment is being encouraged, given focus in the country on entrepreneurship (Muofhe \& Du Toit 2011).

The model by Dyer (1994) focusing on entrepreneurial careers proposes three components on which entrepreneurial careers are grounded on namely career selection, career socialisation and career development. The model by Dyer (1994) further posits that entrepreneurial choice is a variable, which is influenced by individual and economic factors. Within this, the role of education is deemed as an important factor in preparing an individual to become an entrepreneur (Dyer 1994).

\section{Factors influencing entrepreneurial intent}

Some factors have been found to influence entrepreneurial intent. As a general guideline, these factors can be grouped as

TABLE 1: Examples of studies using media sources to understand careers and career development.

\begin{tabular}{llll}
\hline Author(s) & Country & Source of data & Salient issue being investigated \\
\hline Wilks (2012) & United States of America & Television Series - Greys Anatomy & Career narratives of women in organisations. \\
Spiker (2012) & United States of America & Movie - Devil Wears Prada & Power dynamics in careers. \\
Cohen and Duberley (2013) & United Kingdom & Music - BBC Desert Island Discs & The performative dimension of careers and career development. \\
LaPointe and Heilmann (2014) & Finland & Magazine and newspaper articles & Narratives of career change and the meaning of work. \\
\hline
\end{tabular}

Source: Author's own work 
either individual or societal to include those factors specific to the political and socio-economic situation of the country (Farrington et al. 2012). In a study conducted by Muofhe and Du Toit (2011), entrepreneurship education was found to influence entrepreneurial intentions among a sample of students. In the same study, role models were also found to influence students' entrepreneurial intentions. Based on the findings by Muofhe and Du Toit (2011), the implication here could be that individuals are actually gaining an understanding into how career development works (Mitchell, Levin \& Krumboltz 1999).

In essence, such activities help the individual prepare for the world of work and the accompanying roles (Gibson 2004). In light of the previous statement, individuals also develop a way of mastering their past in relation to current and future activities shaping them (Gibson 2004). Janis and Mann (1977) view such individuals as learning by making small or incremental decisions in preparation for the world of work or becoming an entrepreneur or a concept referred to as the 'art of muddling through' (Stead \& Watson 2006:97) and thus can represent a basis on which career decisions are made based on learning from such experiences.

Others attribute (e.g. Roberts 2000) the motive to be an entrepreneur to be influenced by an experience of constraints and how these affect individual traits, thus forcing the individual to take action. In South Africa, a number of constraints can potentially exert action into a consideration of a career as an entrepreneur, namely, gender (Geldenhuys \& de Lange 2007), lack of funds (Goyal \& Parkash 2011) and poverty (Xaba \& Malindi 2010). Constraints may also exist from the environment. Urban (2010a) found a correlation to exist between entrepreneurial orientation, environmental hostility and dynamism. The implication here could be that through the conditions and events of the environment, individuals may develop not only skills that have a bearing on their career preferences (Watson et al., 2001; Krumboltz 1994) but also direct concrete efforts towards making a career choice (Chinyamurindi 2012, 2016a, 2016b).

Given this, the focus of this research is to explore lessons that can be learnt from a television show aired in South Africa called 'Against All Odds' showcasing the careers of entrepreneurs and how this can be a useful tool for entrepreneurship education. The thinking here is that individuals are motivated towards self-employment given the 'great narratives of our times' (Inkson 2007:231; Savickas 2011) and by tapping into these useful accounts, insights of current and potential entrepreneurs can be gathered and used in education. Narrowly, the focus of this study is on black entrepreneurs especially those disadvantaged by the policy of apartheid. The justification for this is that such a sample has been advocated for in South Africa as an important sample group that is often neglected in empirical studies even though this sample group occupies an important social justice agenda (Chinyamurindi 2012, 2016a, 2016b).

\section{Purpose and primary objective}

Based on the narratives and stories of black entrepreneurs, the goal of this research is to understand the lived experience career entrepreneurs. The research is guided by the research question: 'what factors influence the motivation to consider entrepreneurship as a career choice among a sample of black South Africans?' Further, in seeking to answer this research question, the research draws implications that affect entrepreneurship career development education.

\section{Research method and design}

A qualitative paradigm using a narrative and story-based inquiry was chosen due to the perceived strength this method has. Firstly, studies in South Africa on entrepreneurship have mostly taken a quantitative approach. Calls have been made for studies within the entrepreneurship stream that advance theory (Zahra 2007) as often done by the qualitative approach. Further, calls in a South African context have been made for more studies that strive to build 'additional conceptual bridges' within entrepreneurship research (Urban 2008:28). An opportunity exists here for qualitative research given that the method is gaining popularity in South Africa both within research on entrepreneurship (Pretorius \& Le Roux 2011; Serfontein, Basson \& Burden 2009) and the career literature (Chinyamurindi 2012, 2016a, 2016b; Geldenhuys \& de Lange 2007; Pheko 2014).

\section{Sampling and data collection}

The interviews of an independent media house in South Africa were downloaded from the YouTube channel. A total of 60 shows of 10 - and 15-minutes' duration were downloaded. Even though the video clips are available on a public portal, permission was granted for use of these video clips in not only teaching practice but also writing journal articles. The researcher also applied for ethical clearance with the institute of affiliation before collecting and analysing the data.

A non-probability judgemental sampling approach among the 60 shows that were initially downloaded was applied. The purpose here was twofold. Firstly, some shows did not include entrepreneur stories and focussed on the lives of sports, political and entertainment personalities. The inclusion criterion was that the story needed to be of an entrepreneur. Secondly, the study needed the stories of previously disadvantaged black entrepreneurs for its empirical focus. This resulted in a number of shows to be excluded. From 60 shows, only 13 were deemed usable for the purpose of this research. Table 2 reports on these participants:

\section{Reliability and validity (rigour or trustworthiness)}

As guided by literature (Golafshani 2003), the researcher implemented relevant steps to ensure rigour of the study's findings. Firstly, to ensure credible data, all data collected were recorded and transcribed verbatim as was viewed from the television show. Secondly, during the process of generating 
TABLE 2: Participants to the research.

\begin{tabular}{|c|c|c|c|}
\hline Name of entrepreneur & Gender & Type of start-up & Salient comment \\
\hline Ouma Tema & Female & Clothes Designer & Ouma started her own company to make clothes for plus size women. \\
\hline Max Lichaba & Male & Jeweller & Max broke into a previously 'white' profession and started his own jewellery store. \\
\hline Nontwenhle Mchunu & Female & Nandi's Chocolate & Nandi's chocolate is one of South Africa's first black-owned chocolate makers. \\
\hline Matthews Mogafe & Male & Funeral Services Company & Matthews started off by selling oranges and peanuts. \\
\hline Kedi Mathope & Male & Hospital Equipment Distributor & Kedi grew up in a poor home and draw from this experience in becoming an entrepreneur. \\
\hline Linda Twala & Female & Coffin Manufacturing & Linda noticed a need in her community for affordable coffins. \\
\hline Lere Mgayiya & Male & Lere's Shoe Shine & Lere's businesses can be spotted in South African airports offering shoe-shinning services. \\
\hline Grace Masuku & Female & Museum Founder & Grace was interested in preserving her cultural heritage and started her own museum. \\
\hline Brian Mbambo & Male & Training Consultancy & An accident of a loved one caused Brian to start a company offering training services. \\
\hline Lebohang Khitsane & Male & Bataung Memorials & Lebohang has created an app that helps people find parking space at funerals. \\
\hline Tembeka van Wyk & Female & Merchandise and Distributor & Tembeka walked out of a successful practice to follow her dream of starting her own company. \\
\hline Khwezi Sikwebi & Male & Tombstone Manufacturer & Khwezi came out of prison to start his own company. \\
\hline
\end{tabular}

Source: Author's own work

themes, two other academics that work and teach entrepreneurship and business management scrutinised the identified themes. The initial themes were refined and presented back to the two academics for further scrutiny. Thirdly, before and during the study, reflexivity was used, as a process, to enforce objectivity and shun potential bias; this was also done to ensure sensitivity with regard to the data management process. In doing so, comprehensive notes were taken at all key stages of the research for additional depth and quality.

\section{Coding framework and analyses}

The interviews were exported into QSR International's NVivo 9 , a data analysis and management software package useful when dealing with a lot of text, graphic, audio and video data (Chinyamurindi 2016a, 2016b). A data analysis procedure based on three levels of meaning-making, as adopted in previous research, was used (e.g. Chinyamurindi 2012, 2016a, 2016b; McCormack 2000). Table 3 represents the stages of the levels of meaning-making adopted used for data analysis.

\section{Ethical considerations}

The researcher adhered to institutional ethical requirements. This was done by applying for ethical clearance through the relevant institutional body. Further, given that the data used for this research project belonged to the independent television station. Permission was sought for through the station's legal and production department.

\section{Results}

Based on the participant stories and narratives, three main themes emerged as lessons from the lived experience of the entrepreneurs used in this study. These themes are presented in terms of opportunities of entrepreneurship: (a) entrepreneurship: an opportunity out of struggle; (b) entrepreneurship: an opportunity for individual selfdevelopment and (c) entrepreneurship: an opportunity for service. Concerns can be raised around arriving at these three main sub-themes.

The results of only 6 of the 13 participants are used to illustrate the factors that motivate an individual to become an

\begin{tabular}{ll}
$\begin{array}{l}\text { TABLE 3: Data analysis procedure. } \\
\text { Level of } \\
\text { meaning-making }\end{array}$ & Description \\
\hline 1 & $\begin{array}{l}\text { Each interview is written as a brief vignette. Thereafter, } \\
\text { each vignette is then developed into a longer narrative about } \\
\text { each participant. }\end{array}$ \\
\hline $\begin{array}{l}\text { Narrative themes are then conveyed by participants and their } \\
\text { experience of career development. } \\
\text { Thereafter, preliminary themes are then compared across } \\
\text { participants. }\end{array}$ \\
\hline $\begin{array}{l}\text { An analysis of the themes from cross-case comparison } \\
\text { begins and illustrating quotes and stories used. }\end{array}$ \\
\hline
\end{tabular}

Source: Author's own work

entrepreneur for three reasons. Firstly, although all 13 interviews formed part of the narrative analysis, only 6 were used as a point for illustration due to space considerations. Secondly, the three main sub-themes found in this study were all common among the 13 participants, and no other new themes could be generated (Denzin \& Lincoln 2005). This is common in qualitative research because beyond the identified themes, no new information is generated (Ritchie, Lewis \& Elam 2003) as the main idea is around generating meaning and not making generalisations (Crouch \& McKenzie 2006). Finally, the concept of saturation becomes important here because after an analysis of all 13 narratives, no new data could be generated outside the three main sub-themes (Charmaz 2006). Thus, the narratives of the six participants are used in this work to illustrate the three main sub-themes.

Further, there is need to clarify how the three main subthemes emerge from the data of the 13 participants. This appears to be standard practice when dealing with qualitative data that the researcher makes clear the initial codes leading to the identified themes of participant data (Chinyamurindi 2016a, 2016b). Table 4 illustrates the identified main subthemes, including the initial codes supporting the identified themes and the meaning of the theme.

Each of these three main sub-themes is discussed below, including the illustrating quotes and stories.

\section{Entrepreneurship: An opportunity out of struggle}

The individuals interviewed in this research narrated a life of struggle and challenge as not only affecting their personal 
TABLE 4: Initial codes and main themes.

\begin{tabular}{lll}
\hline Initial codes & Main theme & Meaning of main theme \\
\hline $\begin{array}{l}\text { Move out of struggle, financial independence, } \\
\text { change of life, better future and avoid poverty. }\end{array}$ & $\begin{array}{l}\text { Entrepreneurship: An opportunity } \\
\text { out of struggle. }\end{array}$ & $\begin{array}{l}\text { This theme identifies the motivation to become an entrepreneur through a } \\
\text { change from a lifestyle characterised by struggle to one of affluence. }\end{array}$ \\
$\begin{array}{l}\text { Career change, need for independence and } \\
\begin{array}{l}\text { autonomy, earn more money and development } \\
\text { of skills or personal enrichment. }\end{array}\end{array}$ & $\begin{array}{l}\text { Entrepreneurship: An opportunity } \\
\text { for individual self-development. }\end{array}$ & $\begin{array}{l}\text { This theme identifies the motivation to become an entrepreneur based on quests } \\
\text { to improve the lived experience from the vantage of the individual. }\end{array}$ \\
$\begin{array}{l}\text { Help immediate family members, help } \\
\text { community, change lives and live a life of sacrifice. }\end{array}$ & $\begin{array}{l}\text { Entrepreneurship: An } \\
\text { opportunity for service. }\end{array}$ & $\begin{array}{l}\text { This theme identifies the motivation to become an entrepreneur based on } \\
\text { changing the lives of others. }\end{array}$ \\
\hline
\end{tabular}

Source: Author's own work

lives but subsequently informing how these individuals became entrepreneurs. The first variation of this struggle came from an individual's upbringing. For instance, Kwezi stayed in one of South Africa's toughest townships and turned to crime from a young age:

'When my father was shot, it was just tough, we couldn't cope, but my mother tried to stay strong for us. With my friends, we started to hijack trucks and stole cars.'

Kwezi, from a young age, turned to crime to help and support his mother for their daily sustenance. However, a turning point for Kwezi was his imprisonment for his crime. Sentenced to spend 10 years in jail, Kwezi turned to education in a bid to improve himself while in prison:

'The morning I woke up seeing all the other prisoners, the bunks and the uniform ... that's when it hit me, I will be in here for ten years. I turned to education because I wanted to become a better person and I wanted to help others.'

Upon leaving prison, Kwezi struggled to get into mainstream employment because of his criminal record, and he turned to some local businesses for a chance to learn how to run his own business. Some local businesses offered him a chance to learn and subsequently, he set up his own tombstone manufacturing company. In light of this, Kwezi appears buoyant and reflective about being an entrepreneur, an experience borne from his personal and community struggle:

'Due to the bad things I had done in my community, I felt bad; I was remorseful for what I had done. I really wanted to make a difference; I really wanted to rectify my mistake.'

Some participants narrated struggles that were not only environmental but also personal. Lebohang had started a business at the age of 20 - Lebo Printers. The business was doing well and had a broad clientele. However, the failure of the business was rooted in the one who started it:

'When I went to night clubs, people knew me. Everywhere I went, everyone knew me. After some time, I lost everything I had worked hard for.'

To Lebohang, the crumbling of his business empire appeared to be a struggle that was painful. However, from this experience, Lebohang set his sights again on building a new empire and now runs Bataung Memorials. While starting up his business venture, Lebohang expanded his tentacles when he noticed a struggle affecting his community, especially when a funeral occurs.

'On a busy weekend when there are dozens of funerals taking place at the same time, it gets chaotic and confusing, as a result mourners waste a lot of time looking and trying to locate the right procession. I created a GPS coordinate for grave sites, a QR code that also has funeral programmes. You can leave a message to the family, you can get directions to the grave side and you won't get lost.'

The narratives and stories of the participants in this research point to entrepreneurship as emerging not only out of struggles in the community but also from personal individual struggles. Thus, such struggles can be positioned as a paradox. In one sense, they limited individual advancement but in the other sense served as beacons through which individuals use such struggles as stepping stones to become entrepreneurs. Linked to a career into entrepreneurship emerging from struggle is the quest in becoming an entrepreneur due to opportunity for individual self-development.

\section{Entrepreneurship: An opportunity for individual self-development}

In some stories, individuals showed a great deal of agency in their efforts to become entrepreneurs. For instance, Lere is well known in South Africa for his shoe-shine businesses that can be found at every airport. Entrepreneurship for Lere appeared to be born out a quest for wanting more opportunity for individual self-development. For Lere, this entailed a lot of job hopping:

'I started off as a checking agent for South African airways straight after completing my matric (high school). After one year, I decided to quit and go into the family business in Cape Town. After one year, they fired me from the family business. It was from this I decided to start my own business.'

Interestingly, Lere identified a gap in the market based on the first experiences from his first job. He noticed that there was a great deal of shoe-shining services, mostly in the commercial hub in the cities he stayed in. However, he saw no one had thought of introducing a shoe-shinning service within South African airports, given that at the time, he worked as a checking agent at South African Airways. For Lere, opportunity to become an entrepreneur is not only woven from quests of personal and individual development but also in turning to his life experiences. These life experiences, though distinct, appear to be inter-related in the forming of a career as an entrepreneur.

Jonas started off studying for a career in biochemistry with a leading South African university. In 2010, he could not afford to pay for his university enrolment fees. As a result, he stayed at home. From where he was, Jonas wanted to develop not only his talent in animation but also an entrepreneurial spirit: 
'I just decided you know what, I'm going to do something; I'm going to teach myself something that I've always wanted to learn. I got a small model and got information from the internet on how to create animations. I guess you can say that art imitates life, so every time I just think about things that happen around me, I create animations.'

Jonas showed aspects of vocational and entrepreneurial aspiration albeit his challenges of finances. Through this experience, an entrepreneurial career path appears to emerge. From the quote above, Jonas appears to be unmoved by his condition of disadvantage. This rather unintentionally appears to be a catalyst for him turning to a career in animation. Finally and linked to the two previous themes, participants, in their stories and narratives, also expressed the opportunity found in entrepreneurship as a basis for service to community.

\section{Entrepreneurship: An opportunity for service}

Participants such as Brian cited their journey into becoming entrepreneurs as emerging from ideals of community service. In the case of Brian, this happened through an unfortunate accident:

'A call came in that my relative was involved in a car accident. I had to rush where she was and because she was crying, you could hear in her voice that she was really hurt. I noticed there was no ambulance at the scene of the accident. On the scene were tow-truck drivers. These guys could not even control traffic or do scene management.'

After Brian's relative had recovered from the accident, Brian decided to start a training consultancy, which he now heads. The idea was to offer training opportunities to tow truck drivers as they usually arrive first at the scene of an accident. Brian's journey on becoming an entrepreneur appears to be born out of an unfortunate incident affecting his relative. From this, Brian left formal employment to start up his own consulting company; the idea was to serve his community while also making money.

Others like Grace started their business ventures motivated by the need to preserve cultural heritage in her community. Grace regards herself as a proud custodian of cultural heritage in South Africa:

'I was exposed to the whole Bophuthatswana. I was exposed to Thabantshu to Mariswane. In the past 12 years, I have come into contact with all cultures in the Bophuthatswana, Xhosa, Sotho, Tswana and Pedi cultures. I have got this rich information in me.'

Grace felt she had to give back to her community and preserve this rich cultural heritage in her. She started a cultural museum where she teaches and trains people on knowing their heritage. Though receiving numerous awards for her contribution, Grace feels that all this is her act of service based upon her knowledge. The significance and implications of these three themes, based on the narratives and stories of entrepreneurs, are discussed next.

\section{Discussion of findings}

This research analysed career narratives of entrepreneurs operating in South Africa and drew some lessons to be used with regards to entrepreneurship teaching. The main themes that emerged from this study, based on participant stories and narratives were the following: (a) entrepreneurship: an opportunity out of struggle; (b) entrepreneurship: an opportunity for individual self-development and (c) entrepreneurship: an opportunity for service. The journey of individuals becoming career entrepreneurs happened in the adult stage of their lives influenced by factors such as formal and informal learning activities (Stokes, Wilson \& Mador 2010), role models (Gibson 2004) and individual agency (Dyer 1994). This work also illustrates that the journey to becoming entrepreneurs is influenced by a set of unintentional events (e.g. accidents) and intentional experiences (efforts planned by the individual) (Patton \& McMahon 2006).

Further, the role and influence of individuals close to the entrepreneurs in this research should not be underestimated. In some cases, these individuals served as a source of motivation and for some, they existed as an information hub in helping charter paths into entrepreneurship. It would appear, based on theorising, that individuals such as friends, parents and relations were trusted because of their relevance, credibility and knowledge.

This research adds further into the growing inquiry of developing entrepreneurship as a career (Ghina 2014; Pardo 2013; Wolhuter 2011) using a somewhat novel data set (Cohen \& Duberley 2013). Through individual experiences, be they positive or negative, some form of learning experience that allowed for steps towards entrepreneurship was acquired. In this, individuals could re-story their lives (Harmeling 2011). The ultimate here really was to serve others and change individual circumstances, thus showing support to the idea that entrepreneurship is influenced by not only individual but also contextual forces (Dyer 1994; Muofhe \& Du Toit 2011). Through the findings of this research, further light is shed onto the qualities and skills needed to be an entrepreneur.

\section{Contribution}

Using and analysing the stories and narratives of black entrepreneurs in South Africa appeared to offer a means of understanding not only the individual but their history, present and future aspiration (Gibson 2004). Based on these participants' stories, there are a variety of systemic influences within the individual context that influence career development (Patton \& McMahon 2006). These ranged from intrapersonal factors (likes and dislikes of personal situations and conditions, thus leading the individual to become an entrepreneur), social factors (e.g. the role of family, friends, guardians, teachers and networks near the entrepreneur) and, finally, environmental-societal factors (the role of community and its members). 
The career progression of entrepreneurs was found to be not only dynamic but also complex (Savickas 2011). This finding shed light onto the nature of career development processes, especially for those individuals en route to becoming entrepreneurs. The findings of this work reveal processes that do not support the traditional idea of career espoused in seminal theories of a process that is linear, predictable (Maree 2015) and consistent with studies advocating a rethink in how careers and career development is understood (LaPointe \& Heilmann 2014). The use of stories and narratives, as a research technique, made it possible to establish the beginning, middle and end (Maree 2014) of events shaping the individual experience. This research was not restricted to just one moment of the individual's experience but took into consideration a 'holistic approach' (Del Corso \& Rehfuss 2011:338) rather than one that is discrete and often fragmented as utilised in survey-based techniques.

\section{Implications for entrepreneurship education}

Based on the findings of this research, five issues serve as implications to the field of entrepreneurship based on career entrepreneur narratives. Firstly, ordinary citizens can become entrepreneurs. The individual stories used in this research all show similarity in that all the participants were ordinary South Africans. Thus, educators need to frame entrepreneurship education not as an exclusive practice or conclave of an elite group. The participants used in this research show this to be contrary. In essence, by showing that anyone can be an entrepreneur is giving students space and room to develop in finding individual core competencies through learning (Mitchell et al. 1999). This then allows for self-expression and individual agency (Schreuder \& Coetzee 2013) and can indicate the performative dimension of careers (Cohen \& Duberley 2013).

Secondly, educators can use narratives (as done in this research) to inspire and cultivate a culture of entrepreneurial learning. Given that the narratives and stories used in this research are context-specific, this can allow learners the opportunity and a chance to relate with not only the lives of entrepreneurs but also the practice of entrepreneurship. This allows for students to identify with lives of entrepreneurs used in this research as role models (Dyer 1994; Muofhe \& Du Toit 2011). The thinking here is that through teaching and learning from the lives of entrepreneurs, one can move to become an entrepreneur (Levie 1999).

Thirdly, the narratives and stories of participants in the research pointed to the value of informal learning en route to becoming an entrepreneur (Stokes et al. 2010). Participants in this research mentioned having gone through various channels in which they learnt about personal interests, likes and dislikes. From this, these individuals then channelled such efforts in their entrepreneurial pursuits. Educators should encourage learners not to underestimate the value of informal learning in building the entrepreneur. Such efforts offer a channel not only to understand careers within the context of work (Gibson 2004) but also the opportunity for self-discovery (Schreuder \& Coetzee 2013). Thus, informal learning can exist as a practical effort in entrepreneurship education. Further, informal learning through participant stories illustrated how individuals craft themselves in becoming entrepreneurs (Ibarra \& Petriglieri 2010). This study thus advances and responds to calls advancing entrepreneurial education (Ghina 2014).

Fourthly, educators need to position entrepreneurship as a lifelong, holistic and linked experience. Participants in this research spoke of breaking societal and individual barriers that appear to be all linked to the lived experience, though serving as constraints (Roberts 2000). Thus, educators need to encourage learners to see their life story not as one fragmented piece but one that is interlinked to and influenced by cultural issues (Stead et al. 2001) and the environment (Urban 2010b). In essence, entrepreneurship education thus should emphasise on a holistic rather than fragmented development and inquiry of the individual. Finally, based on the narratives of participants in this research, failure emerged as part of the entrepreneur story. Educators need not only present a 'romanticised' view of entrepreneurship but also reveal the accompanying challenges and complexities of such careers. This obviously requires a balancing act as the aim here is to also alert learners of the positives of being an entrepreneur while also not ignoring the inevitable challenges accompanying such roles. This here is a paradox.

\section{Limitations}

This study has some limitations that deserve to be noted. Firstly, the sample is not generalisable to the entire population of black entrepreneurs or those who were previously disadvantaged in South Africa. Secondly, as with qualitative research, the research sample is small. The point here was illustrated using a small sample (not generalisable) but for the purpose of making an argument, be it theoretical in the value of narratives within the careers and entrepreneurship research. Thirdly, the narratives were generated from interviews conducted by the presenter of the show 'Against All Odds'. From a distance, the author of the paper could only work with what was asked by the presenter of the show to the entrepreneur. However, the issue here is through the generation of a narrative to understand a phenomenon, not to unearth truth.

\section{Future research}

Future research could be broad incorporation of other racial groups not used in this study. Future research could also make a cross-comparison between male and female entrepreneurs' experiences as a basis for proposing interventions in even addressing the gender divide. Finally, future research could unpack further the influence of factors found in this study and the role of context (sociohistorical consideration and cultural milieu) in shaping career entrepreneurs. Interestingly, this can include the role of networks, not only in how they affect the way entrepreneurs start off but also their further development. This can be a 
future agenda of developing localised instruments on entrepreneurship careers. Entrepreneurship education, as a discipline, would benefit from such avenues of inquiry.

\section{Conclusion}

This study gives attention to factors that influence entrepreneurial behaviour and consideration of entrepreneurship as a career path with some implications for encouraging self-employment through entrepreneurship education. The identified factors in this study were found not only too complex but key in shaping the career development of individuals and shaping the lived experience. The findings provide a basis for future research appealing to the academic press, especially using 'understudied' (Schreuder \& Coetzee 2012:44) black entrepreneurs within the careers literature, albeit the ramifications on issues of social justice and equity.

\section{Acknowledgements Competing interests}

The author declares that he has no financial or personal relationships which may have inappropriately influenced him in writing this article.

\section{Authors' contributions}

W.T.C. conceptualised the study and the subsequent writing of this article. W.T.C. also acknowledges funding from the Govan Mbeki Research Development Centre at the University of Fort Hare. This funding helped pay for the transcription of data.

\section{References}

Charmaz, K., 2006, Constructing grounded theory: A practical guide through qualitative analysis, Sage, London.

Chimucheka, T., 2014, 'Entrepreneurship education in South Africa', Mediterranean Journal of Social Sciences 5(2), 403-416. http://dx.doi.org/10.5901/mjss.2014. v5n2p403

Chinyamurindi, W.T., 2012, 'Stories of career change amongst distance learners in South Africa', South African Journal of Human Resource Management 10(2), 1-11.

Chinyamurindi, W.T., 2016a, 'Using narrative analysis to understand factors influencing career choice amongst a sample of distance learning students in South Africa' South African Journal of Psychology 46(3) 390-400.

Chinyamurindi, W.T., 2016b, 'A narrative investigation into the meaning and experience of career success: Perspectives from women participants', South African Journal of Human Resource Management 14(1), 1-11. http://dx.doi.org/10.4102/sajhrm. v14i1.659

Christensen, T.K. \& Johnston, J.A., 2003, 'Incorporating the narrative in caree planning', Journal of Career Development 29, 149-160. http://dx.doi.org/10.1023/ A:1021462028524

Cohen, L. \& Duberley, J., 2013, 'Constructing careers through narrative and music: An analysis of Desert Island Discs', Journal of Vocational Behavior 82(3), 165-175. $\mathrm{http}: / /$ dx.doi.org/10.1016/j.jvb.2013.01.010

Crouch, M. \& McKenzie, H., 2006, 'The logic of small samples in interview based qualitative research', Social Science Information 45(4), 483-499. http://dx.doi. org/10.1177/0539018406069584

Del Corso, J. \& Rehfuss, M.C., 2011, 'The role of narrative in career construction theory', Journal of Vocational Behaviour 79(2), 334-339. http://dx.doi.org/10. 1016/j.jvb.2011.04.003

Denzin, N.K. \& Lincoln, Y.S., 2005, 'Introduction: The discipline and practice of qualitative research', in N.K. Denzin \& Y.S. Lincoln (eds.), The Sage handbook of qualitative research, 2 nd edn., Sage, Thousand Oaks, CA.

Dyer, W.G., 1994, 'Toward a theory of entrepreneurial careers', Entrepreneurship Theory and Practice 19, 7-21.

Fairclough, N., 1995, Media discourse, Edward Arnold, London.
Farrington, S., Venter, D., Schrage, C. \& van der Meer, P., 2012, 'Entrepreneurial attributes of undergraduate business students: A three country comparison revisited', South African Journal of Economic and Management Sciences 15(4), revisited',
$333-351$.

Fatoki, I,O. \& Garwe, D., 2010, 'Obstacles to the growth of new SMEs in South Africa: A principal Component analysis approach', African Journal of Business Management 4(5), 729-738.

Fayolle, A. \& Gailly, B., 2008, 'Teaching models and learning processes in entrepreneurship education', Journal of European Industrial Training 32(7), 569-593. http://dx.doi.org/10.1108/03090590810899838

Feldman, D.C. \& Bolino, M.C., 1996, 'Careers within careers: Reconceptualising the nature of career anchors and their consequences', Human Resource Management Review 6(2), 89-112. http://dx.doi.org/10.1016/S1053-4822(96)90014-5

Geldenhuys, J. \& de Lange, N., 2007, 'Career identities of first-year female coloured students', South African Journal of Education 27, 117-137.

Ghina, A., 2014, 'Effectiveness of entrepreneurship education in higher education institutions', Procedia-Social and Behavioral Sciences 115, 332-345. http://dx.doi org/10.1016/j.sbspro.2014.02.440

Gibson, D.E., 2004, 'Role models in career development: New directions for theory and research', Journal of Vocational Behavior 65(1), 134-156. http://dx.doi. org/10.1016/S0001-8791(03)00051-4

Golafshani, N., 2003, 'Understanding reliability and validity in qualitative research', The Qualitative Report 8(4), 597-607.

Goyal, M. \& Prakash, J., 2011, 'Women entrepreneurship in India-problems \& prospects', International Journal of Multidisciplinary Research 1(5), 195-207.

Harmeling, S., 2011, 'Re-storying an entrepreneurial identity: Education, experience and self-narrative', Education + Training 53(8/9), 741-749.

Harte, V. \& Stewart, J. 2012, 'Develop, evaluate, embed \& sustain: enterprise education for keeps', Education+Training 54(6), 330-339.

Ibarra, H. \& Petriglieri, J.L., 2010, 'Identity work and play', Journal of Organizationa Change Management 23(1), 10-25. http://dx.doi.org/10.1108/095348110110 17180

Inkson, K., 2007, Understanding careers: The Metaphors of working lives, Sage, Thousand Oaks, CA.

Janis, I.L. \& Mann, L., 1977, Decision-making: A psychological analysis of conflict, choice, and commitment, Free Press, New York.

Krumboltz, J.D., 1994, 'The Career beliefs inventory', Journal of Counseling and Development 72, 424-428. http://dx.doi.org/10.1002/j.1556-6676.1994.tb00962.x

LaPointe, K. \& Heilmann, P., 2014, “'Daring leaps" Construction of meaning and individual agency in career change narratives in the media', Nordic Journal of Working Life Studies 4(2), 47-64. http://dx.doi.org/10.19154/njwls.v4i2.3864

Levie, J., 1999, Entrepreneurship education in higher education in England - A survey, London Business School, London.

Maree, J.G., 2014, 'Career construction with a gay client: A case study', British Journa of Guidance \& Counselling 42, 436-449. http://dx.doi.org/10.1080/03069885.20 14.886670

Maree, J.G., 2015, 'Career construction counseling: A thematic analysis of outcomes for four clients', Journal of Vocational Behavior 86, 1-9. http://dx.doi.org/ 10.1016/j.jvb.2014.10.001

Maritz, A., Jones, C. \& Shwetzer, C., 2015, 'The status of entrepreneurship education in Australian universities', Education + Training 57(8/9), 1020-1035.

McCormack, C., 2000, 'From interview transcript to interpretative story: Part 1. Viewing the transcript through multiple lenses', Field Methods 12(4), 282-297. $\mathrm{http}: / / \mathrm{dx}$.doi.org/10.1177/1525822X0001200402

Mitchell, K.E., Levin, A.S. \& Krumboltz, J.D., 1999, 'Planned happenstance: Constructing unexpected career opportunities', Journal of Counseling \& Development 77, 115125. http://dx.doi.org/10.1002/j.1556-6676.1999.tb02431.x

Muofhe, N.J. \& Du Toit, W., 2011, 'Entrepreneurial education's and role models' influence on career choice', South African Journal of Human Resource Management 9(1), 1-15. http://dx.doi.org/10.4102/sajhrm.v9i1.345

Pardo, C.A., 2013, 'Is business creation the mean or the end of entrepreneurship education? A multiple case study exploring teaching goals in entrepreneurship education', Journal of Technology Management \& Innovation 8(1), 1-10. http:// dx.doi.org/10.4067/S0718-27242013000100001

Patton, W. \& McMahon, M., 2006, Career development and systems theory: Connecting theory and practice, Sense Publishers, Rotterdam.

Pheko, M.M., 2014, 'Batswana female managers' career experiences and perspectives on corporate mobility and success', South African Journal of Human Resource Management 12(1), 1-11. http://dx.doi.org/10.4102/sajhrm.v12i1.445

Pretorius, M. \& Le Roux, I., 2011, 'Successive failure, repeat entrepreneurship and no learning: A case study', South African Journal of Human Resources Management 9(1), 1-13. http://dx.doi.org/10.4102/sajhrm.v9i1.236

Ritchie, J., Lewis, J. \& Elam, G., 2003, 'Qualitative research practice: A guide for social science students and researchers', in J. Ritchie \& J. Lewis (eds.), Qualitative research practice: A guide for social science students and researchers, Sage, London.

Roberts, K., 2000, 'Cause for optimism: Current reforms can work', Careers Guidance Today 8(5), 25-27.

Savickas, M.L., 2011, 'Constructing careers: Actor, agent, and author', Journal of Employment Counseling 48, 179-181. http://dx.doi.org/10.1002/j.2161-1920. 2011.tb01109.x 
Schreuder, D. \& Coetzee, M., 2012, 'A review of four decades of research in organisational career psychology by academia in South Africa', South African Journal of Human Resource Management 10(2), 1-10. http://dx.doi.org/10.4102/sajhrm.v10i2.474

Schreuder, D. \& Coetzee, M., 2013, Careers: An organisational perspective, Juta, Cape Town.

Serfontein, S., Basson, J.S. \& Burden, J. 2009, 'Mapping a transformation from a traditional to an entrepreneurial organisation: A South African case', South African Journal of Human Resource Management 7(1), 1-14.

Shen, H. \& Yuan, Y., 2013, 'Complexities of Confucian entrepreneurs: Narratives of transnational Chinese scholar entrepreneurs', International Journal of Liberal Arts and Social Science 1(1), 61-70.

Spiker, J.A., 2012, 'Gender and power in the devil wears Prada', International Journal of Business, Humanities and Technology 2(3), 16-26.

Stead, G.B. \& Watson, M.B. (eds.), 2006, Career psychology in the South African context, Van Schaik Publishers, Pretoria.

Stead, G.B., Watson, M.B., Gallant, E. \& Sauls, F.A., 2001, 'Occupational awareness inventory: Psychometric properties among South African students', paper presented at the annual meeting of the American Psychological Association, San Francisco, CA

Stokes, D., Wilson, N. \& Mador, M., 2010, Entrepreneurship, Cengage Learning, South Western.

Urban, B., 2008, 'Insights into social entrepreneurship and associated skills', International Journal of Entrepreneurial Behaviour and Research 14(3), 46-364.
Urban, B., 2010a, 'A gender perspective on career preferences and entrepreneurial self-efficacy', South African Journal of Human Resource Management 8(1), 1-8. http://dx.doi.org/10.4102/sajhrm.v8i1.293

Urban, B., 2010b, 'Technology and entrepreneurial orientation at the organisational level in the Johannesburg area', South African Journal of Human Resource Management 8(1), 1-9. http://dx.doi.org/10.4102/sajhrm.v8i1.212

Watson, M.B., Brand, H.J., Stead, G.B. \& Ellis, R.R., 2001, 'Confirmatory factor analysis of the career decision-making self-efficacy scale among South African university students', South African Journal of Industrial Psychology 27(1), 43-46. http://dx. doi.org/10.4102/sajip.v27i1.774

White, M., 2007, Maps of narrative practice, W.W. Norton, New York.

Wilks, L., 2012, 'Is Grey's Anatomy on the Wave? A feminist textual analysis of Meredith Grey and Cristina Yang. Undergraduate student research awards', viewed 22 April 2016, from http://digitalcommons.trinity.edu/infolit_usra/7

Wolhuter, C., 2011, 'The international impact of education research done and published in South Africa', South African Journal of Education 31(4), 603-616.

Xaba, M. \& Malindi, M., 2010, 'Entrepreneurial orientation and practice: Three case examples of historically disadvantaged primary schools', South African Journal of Education 30, 75-89.

Zahra, S.A., 2007, 'Contextualising theory building in entrepreneurship research', Journal of Business Venturing 22, 443-452. http://dx.doi.org/10.1016/j.jbusvent. 2006.04.007 